\title{
Prevalence and antimicrobial susceptibility patterns of Staphylococcus aureus isolated from different clinical sources
}

\author{
*Aliaa Abdelghafar ${ }^{1}$, Nehal Yousef ${ }^{2}$ and Momen Askoura $^{3}$ \\ Department of Microbiology and Immunology, Faculty of pharmacy, Zagazig University, Egypt \\ 1'dr306aliaa@gmail.com, ${ }^{2}$ dr.nehalyousef@gmail.com, ${ }^{3}$ momenaskora@yahoo.com.
}

Received:2 Jan 2020 /Accepted: 22 Mar 2020 /Published online : 20 Jul 2020

\begin{abstract}
Staphylococcus aureus is a Gram positive bacterium living as a commensal on skin, mouth and upper respiratory system, making it a risk factor for opportunistic and nosocomial infections. It is the major cause of skin, bone, pneumonia, soft tissue, and urinary tract infections and other invasive infections in both the community and hospital settings. High prevalence of MethicillinResistant Staphylococcus aureus (MRSA) strains between staphylococcal isolates is very problematic. MRSA strains are common causes of nosocomial infections and are associated with increased morbidity and mortality. The aim of this study is to characterize prevalence of MRSA isolates and determine antibiotic susceptibility patterns of $\mathrm{S}$. aureus clinical isolates toward various antibiotics by disc diffusion method. S. aureus isolates showed high resistance to both $\beta$-lactams and tetracycline and intermediate resistance to gentamycin, azithromycin and erythromycin. However, low bacterial resistance was noted against chloramphenicol, ciprofloxacin, clindamycin and sulphamethoxazole-trimethoprim. S. aureus isolates exhibited a higher sensitivity toward linezolid and vancomycin. The current study indicates that linezolid and vancomycin are the most effective antistaphylococcal drugs.
\end{abstract}

Key words: Staphylococcus aureus, Multidrug Resistance, MRSA, Antibiotic Susceptibility.

\section{INTRODUCTION}

S. aureus is a Gram-positive cocci facultative anaerobe, non-motile and nonsporing bacterium (Khattak et al. 2015). S. aureus causes a wide range of illnesses due to its higher capacity to colonize and grow in different kinds of host tissues (Kluytmans et al. 1997). S. aureus is an aggressive pathogen, causing a range of acute and pyogenic infections, including abscesses, bacteremia, central nervous system infections, endocarditis, osteomyelitis, pneumonia, urinary tract infections, chronic and lung infections associated with cystic fibrosis. In addition, $S$. aureus is responsible for several syndromes caused by exotoxins and enterotoxins, including food poisoning and scalded skin and toxic shock syndromes (Lyczak 2002, Projan 1997).

S. aureus infection has been alarming mainly due to its resistance to multiple antibiotics (Stefani et al. 2012). Multidrugresistant $S$. aureus is a common cause of nosocomial infections and is associated with increased morbidity and mortality (Espedido \&Gosbell 2012). Resistance to commonly used antimicrobial drugs is frequently encountered with S. aureus. Some of these mechanisms include; inactivation of antibiotics by the enzymes, decreased affinity for the antibiotics caused by alteration of the target, efflux pumps, and trapping of the antibiotic (Pantosti et al. 2007). As well as higher bacteria capacity to produce biofilm in indwelling medical devices (Manandhar et al. 2018). Biofilms are essentially the extracellular polymeric substances (EPS) that provide unique niches to bacterial cells. Low oxygen availability and nutrient deficiency among others are features of biofilm favoring the development of antibiotic tolerant persister cells (Waters et al. 2016). In addition, biofilm also protect the embedded bacterial cells from the host immune cells thus facilitating the survival of pathogens for a prolonged period (Donlan \&Costerton 2002, McCann et al. 2008, Namvar et al. 2013).

The objective of this study is to characterize both prevalence and antibiotic susceptibility patterns of $\mathrm{S}$. aureus clinical isolates to various antibiotics. 


\section{MATERIALS AND METHODS}

\section{Bacterial isolation and identification}

A total of 233 clinical specimens were collected from patients admitted to Zagazig University Hospitals and burn unit of El-Ahrar Educational Hospital in Zagazig, Egypt. Specimens were collected using sterile containers or sterile cotton swabs according to Blair et al. (1970). Swabs were cultured on the surface of nutrient agar, blood agar and mannitol salt agar pates then incubated at $37^{\circ} \mathrm{C}$ for 24 hours (Winn et al. 2006). All bacterial isolates were identified as $\mathrm{S}$. aureus based on Gram staining, colony morphology and biochemical characters using standard biochemical methods including catalase, oxidase, coagulase, hemolysis on blood agar, mannitol fermentation and gelatin liquefaction tests (Gerhardt et al. 1981).

\section{Antimicrobial susceptibility testing}

The antibiotic susceptibility test was done according to (Bauer et al. 1966). The antibiotic discs used in this study were obtained from Oxide (Hampshire, England). These discs are methicillin (ME, 5 $\mathrm{g}$ ), ceftriaxone (CRO,

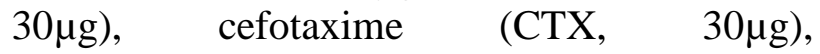
chloramphenicol (C, 30 $\mu \mathrm{g})$, azithromycin (AZM, $15 \mu \mathrm{g}$ ), erythromycin (E, 15 $\mathrm{g}$ ),

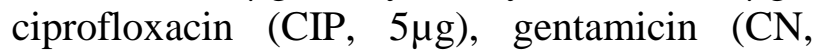
$10 \mu \mathrm{g})$, tetracycline (TE, 30 $\mu \mathrm{g})$, clindamycin (DA, $2 \mu \mathrm{g}$ ), linezolid (LZD, 30 $\mu \mathrm{g}$ ), vancomycin (VA, 30 $\mu$ g), sulphamethoxazole-trimethoprim (SXT, 25 $\mu \mathrm{g}$ ). The antibiotic susceptibility was performed as follows: bacterial suspensions were prepared from overnight cultures on Muller-Hinton (MH) agar (Oxoid, Hampshire, England). Bacterial density was adjusted to 0.5 McFarland standard which corresponds to approximately $(1.5 \times 108 \mathrm{CFU} / \mathrm{mL})$. The surface of MH agar plate was evenly inoculated with bacterial suspensions using sterile swabs. Plates were dried before applying the antibiotic discs, incubated overnight at $37^{\circ} \mathrm{C}$. The diameters of inhibition zones around discs were measured and results were interpreted according to Clinical Laboratory Standards Institute guidelines (CLSI, 2018).

\section{RESULTS}

\section{Isolation and identification of staphylococcal isolates}

A total of 103 isolates were obtained from different clinical sources as shown in table 1. S. aureus isolates were identified microscopically as Gram positive cocci arranged in bunches. They were confirmed biochemically as shown in table 2.

Table 1: Source and number of S. aureus isolates

\begin{tabular}{|l|c|}
\hline \multicolumn{1}{|c|}{ Source } & $\begin{array}{c}\text { Number (NO) of } \boldsymbol{S} \text {. } \\
\text { aureus isolates }\end{array}$ \\
\hline Burn & 45 \\
\hline Wound \& pus & 33 \\
\hline Eye infection & 5 \\
\hline Ear infection & 3 \\
\hline Endotracheal aspirates & 10 \\
\hline Urine infection & 7 \\
\hline
\end{tabular}

Table 2: Biochemical identification of S. aureus isolates

\begin{tabular}{|l|l|}
\hline \multicolumn{1}{|c|}{ Test } & \multicolumn{1}{c|}{ Result } \\
\hline $\begin{array}{l}\text { Pigmentation on nutrient } \\
\text { agar }\end{array}$ & $\begin{array}{l}\text { Golden yellow } \\
\text { colony }\end{array}$ \\
\hline Catalase test & + \\
\hline Coagulase test & + \\
\hline Oxidase test & + \\
\hline Mannitol fermentation & Mannitol fermentor \\
\hline Hemolysis on blood agar & $\beta$ - hemolysis \\
\hline Gelatin liquefaction & + \\
\hline
\end{tabular}

\section{Antimicrobial susceptibility of $S$. aureus isolates}

As shown in table 3, S. aureus isolates showed complete resistance to methicillin $(100 \%)$. Staphylococcus isolates were highly resistance to cefotaxime and ceftriaxone $(92.2 \%$ each), tetracycline $(63.1 \%)$. Intermediate resistance was found against gentamycin $(47.5 \%)$, erythromycin $(31.1 \%)$ and azithromycin $(30.1 \%)$. Low resistance was found against chloramphenicol (22.3\%), ciprofloxacin (20.4\%), clindamycin (6.7\%), sulphamethoxazole-trimethoprim (5.8\%). All S. aureus isolates showed complete sensitivity to both linezolid and vancomycin (100\%). High frequency of multidrug resistance (MDR) was found among the tested isolates (64\%) as shown in table 4. 
Zagazig J. Pharm. Sci. Jun, 2020

Vol. 30, Issue 1, pp. 1-8

Table 3: Antibiotic resistance profile of S. aureus isolates to different antibiotics

\begin{tabular}{|l|c|}
\hline \multicolumn{1}{|c|}{ Antibiotic disc } & $\begin{array}{c}\text { NO of resistant } \\
\text { isolate (\%) }\end{array}$ \\
\hline Methicillin & $103(100)$ \\
\hline Cefotaxime & $95(92.2)$ \\
\hline Ceftriaxone & $95(92.2)$ \\
\hline Tetracycline & $65(63.1)$ \\
\hline Gentamycin & $49(47.5)$ \\
\hline Azithromycin & $31(30.1)$ \\
\hline Erythromycin & $32(31.1)$ \\
\hline Chloramphenicol & $23(22.3)$ \\
\hline Ciprofloxacin & $21(20.4)$ \\
\hline Clindamycin & $7(6.7)$ \\
\hline $\begin{array}{l}\text { Sulphamethoxazole- } \\
\text { trimethoprim }\end{array}$ & $6(5.8)$ \\
\hline Linezolid & $0(0 \%)$ \\
\hline Vancomycin & $0(0 \%)$ \\
\hline
\end{tabular}

\section{DISCUSSION}

S. aureus is a common opportunistic bacterium responsible for a wide range of diseases such as skin and soft-tissue infections (STIs) (Corrado et al. 2016). S. aureus is also a major cause of food-borne illness worldwide (Hennekinne et al. 2012).

Antibiotics resistance is a critical problem worldwide. It has been found to be increased amongst pathogenic bacteria (Weber \&Rutala 2006). The antibiotic resistance crisis may be attributed to the overuse and misuse of these medications, as well as a lack of new drug development by the pharmaceutical industry due to high cost and challenging regulatory requirements (Gould \&Bal 2013). This study is an attempt to assess prevalence and antimicrobial susceptibility pattern of S. aureus isolates obtained from different sources.

A total of $103 \mathrm{~S}$. aureus were isolated in this study with a prevalence rate of $44.2 \%$. This is similar to that observed by (A. Abbas et al. 2018, El-Daker et al. 2008) who reported a prevalence rate $45.6 \%$ and $48 \%$, respectively). However showed a higher prevalence rate (64.8\% and 58.5\%, respectively). And (Datta et al. 2011) showed a lower prevalence rate (35\%). The major source was found in burn, pus and wound in agreement with (Ahmed et al.
ISSN 1110-5089

ISSN (on-line) 2356_9786

2014, Gitau et al. 2018, Kadry 2016). On the other hand, minor sources were in urine, eye and ear in agreement with (Al-Zoubi et al. 2015, Kadry 2016).

The increased percentage of S. aureus isolated from pus could be attributed to exposure of wounds which makes them more prone to infections and poor hygiene (Gitau et al. 2018).

The isolates recovered were completely resistant to methicillin (100\%) which agrees with (Kadry et al. 2016) who also reported $100 \%$ and similar to (Ahmed et al. 2014) who reported 94\%. While in (Ahmad et al. 2013, Verma et al. 2000) resistance rate was lower ( $80.8 \%$ and $50 \%$ respectively).

Our study show high resistance to ceftriaxone and cefotaxime $(92.2 \%)$. This was similar to (Ahmed et al. 2014) who reported high resistant rate to CTX $(88.9 \%)$, However (Sanjana et al. 2010) reported intermediate resistance $(31.6 \%)$.

Our study show high resistance to tetracycline $(63.1 \%)$. This was similar to (Ahmad et al. 2013, Al-Zoubi et al. 2015) that reported resistance rate were $(68.6 \%$ and $58.4 \%$ respectively), However in (Ahmed et al. 2014) reported higher resistance rate $(90.3 \%)$ and in (Gitau et al. 2018) reported lower resistance rate $33 \%$.

In this study $\mathrm{S}$. aureus isolates show intermediate resistance to gentamycin $47.5 \%$, azithromycin $30.1 \%$ and erythromycin $31.1 \%$. This result agrees with (Dweba et al. 2019) who reported $(47 \%, 37.2 \%$ and $23 \%$ respectively). While result obtained by (Wu et al. 2018) show lower resistance rate to gentamycin $16.7 \%$. However (Marais et al. 2009) showed that high resistant to gentamycin and erythromycin (65.7\% and $78.6 \%$ respectively).

S. aureus isolates show low resistance against chloramphenicol and ciprofloxacin $(22.3 \%$ and $20.4 \%$ respectively). Those findings were in agreement with that mentioned by (Wu et al. 2018) where resistance rates were (23.3\% each). And in (Kumari et al. 2008) showed resistance rate to ciprofloxacin was 22.8\%. While (Marais et al. 2009, Tiwari et al. 
2008) reported higher resistance rate against ciprofloxacin (75.75 \% and $69.7 \%$ respectively). And (Ahmed et al. 2014) reported high resistance to chloramphenicol $61.3 \%$.

In this study $\mathrm{S}$. aureus isolates show low resitance toward clindamycin $6.7 \%$. This finding was similar to (Gitau et al. 2018) that reported resistance rate of $14 \%$. On the other hand (Akanbi et al. 2017, Fluit et al. 2001) reported high resistance rate $(76.7 \%$ and $80 \%$ respectively).

In our study resistance rate against sulphamethoxazole -trimethoprim was $5.8 \%$. That was in accordance to (Liang et al. 2019) who reported $10.7 \%$ resistance rate. On the other hand (Dweba et al. 2019) reported high resistance rate to SXT (58.4\%). While (Wu et al. 2018) reported complete sensitivity to SXT.

S. aureus isolates showed complete sensitivity to linezolid and vancomycin. This finding was similar to (Fluit et al. 2001, Gitau et al. 2018, Liang et al. 2019, Marais et al. 2009). This show that vancomycin is the drug of choice for treating multidrug resistance MRSA infection, however regular monitoring of vancomycin sensitivity and routine testing of other newer glycopeptides like teicoplanin should be carried out. Further, the regular surveillance of hospital associated infections including monitoring antibiotic sensitivity pattern of MRSA and formulation of definite antibiotic policy may be helpful for reducing the incidence of MRSA infection (Sanjana et al. 2010). And linezolid showed a perfect staphylococcus aureus activity but is very expensive (Gitau et al. 2018).

The emergence of multidrug-resistant strains of MRSA is worrisome in the present therapeutic scenario. Multidrug resistance was defined as resistance of the strain towards three or more antibiotics at a given point of time (Tiwari et al. 2008). In this study, 64\% of S. aureus isolates were MDR. This result was similar to (Liang et al. 2019, Styers et al. 2006) who found that $(65 \%, 68.6 \%$ respectively) of $\mathrm{S}$. aureus isolates were MDR. But was not agreed with (Al-Zoubi et al. 2015) at which $31 \%$ S. aureus isolates were MDR. However (Fluit et al. 2001) reported high percentage of MDR was $87 \%$.

\section{Conclusion}

This study shows that S. aureus is the major pathogen associated with soft tissue infections. Also show high prevalence of MRSA isolates and its resistance pattern to wide variety of antibiotic so were are extremely in need for surveillance of MRSA and its antimicrobial profile. The hospital infection control policy and guidelines should be strictly implemented and followed so as to enable the clinicians to deliver better and proper health care to the patient. 
Table 4: Frequency of multidrug resistance isolates of S. aureus

\begin{tabular}{|c|c|c|}
\hline NO. of resistance isolates & NO. of antibiotic classes & $\begin{array}{c}\text { Antibiotic classes } \\
\end{array}$ \\
\hline 4 & & $\begin{array}{l}\beta-\text { Lactam, aminoglycosides, macrolides, } \\
\text { tetracycline, phenicols, lincosamide and } \\
\text { fluroquinolones. }\end{array}$ \\
\hline 1 & 7 & $\begin{array}{l}\beta \text { - Lactam, macrolides, tetracycline, phenicol, } \\
\text { lincosamide, fluroquinolones and folate } \\
\text { pathway antagonism. }\end{array}$ \\
\hline 3 & & $\begin{array}{l}\beta \text { - Lactam, aminoglycosides, macrolides, } \\
\text { tetracycline, fluroquinolones and folate pathway } \\
\text { antagonism. }\end{array}$ \\
\hline 1 & 6 & $\begin{array}{l}\beta-\text { Lactam ,aminoglycosides, macrolides, } \\
\text { tetracycline, phenicols and fluroquinolones }\end{array}$ \\
\hline 3 & 5 & $\begin{array}{l}\beta-\text { Lactam, aminoglycosides, tetracycline, } \\
\text { phenicol and fluroquinolones. }\end{array}$ \\
\hline 4 & \multirow{5}{*}{4} & $\begin{array}{l}\beta-\text { Lactam, aminoglycosides, tetracycline, and } \\
\text { fluroquinolones. }\end{array}$ \\
\hline 3 & & $\begin{array}{l}\beta-\text { Lactam , aminoglycosides ,tetracycline, and } \\
\text { macrolide }\end{array}$ \\
\hline 3 & & $\begin{array}{l}\beta-\text { Lactam, phenicol ,tetracycline , and } \\
\text { macrolide }\end{array}$ \\
\hline 2 & & $\begin{array}{l}\beta-\text { Lactam, phenicol, tetracycline, and } \\
\text { aminoglycosides. }\end{array}$ \\
\hline 1 & & $\begin{array}{l}\beta-\text { Lactam, aminoglycosides, lincosamides and } \\
\text { macrolide }\end{array}$ \\
\hline 22 & \multirow[b]{4}{*}{3} & $\beta$ - Lactam, tetracycline, and aminoglycosides. \\
\hline 8 & & $\beta-$ Lactam, phenicol and tetracycline \\
\hline 6 & & $\beta$ - Lactam, tetracycline, and macrolide \\
\hline 3 & & $\beta$ - Lactam, macrolide and fluroquinolones. \\
\hline
\end{tabular}

\section{References}

A. Abbas H, H. Shaker G, A.H. Hegazy W, A. Baiomy A (2018): Prevalence of multidrug resistant Staphylococci isolated from surgical site infections. Zagazig Journal of Pharmaceutical Sciences 27, 31-38

Ahmad B, Urbas F, Jamil J, Ahmed J, Bashir S (2013): Biocides susceptibility pattern and phenotypic detection of Efflux pump in Staphylococcus aureus isolates from two tertiary hospitals of Pakistan. African Journal of Microbiology Research 7, 3171-3178

Ahmed EF, Gad GF, Abdalla AM, Hasaneen AM, Abdelwahab SF (2014): Prevalence of methicillin resistant Staphylococcus aureus among Egyptian patients after surgical interventions. Surgical infections $15,404-411$

Akanbi OE, Njom HA, Fri J, Otigbu AC, Clarke AM (2017): Antimicrobial susceptibility of Staphylococcus aureus isolated from recreational waters and beach sand in eastern Cape Province of South Africa. International journal of environmental research and public health 14,1001

Al-Zoubi MS, Al-Tayyar IA, Hussein E, Al Jabali A, Khudairat S (2015): Antimicrobial susceptibility pattern of Staphylococcus aureus isolated from clinical specimens in Northern area of Jordan. Iranian journal of microbiology 7 , 265

Bauer A, Kirby W, Sherris JC, Turck M (1966): Antibiotic susceptibility testing by a standardized single disk method. American journal of clinical pathology 45, 493-496

Blair, J.E., Lennette, E.H., and Truant, J.P. (1970). Manual of Clinical Microbiology, 
Bethesda M.D., American Society for Microbiology, 300-303

CLSI (Clinical Laboratory Standards Institute). Performance Standards for Antimicrobial Susceptibility Testing: Twenty-Fifth Informational Supplement (CLSI document M100-S25). Wayne, PA, USA. 2018.

Corrado A, Donato P, Maccari S, Cecchi R, Spadafina T, Arcidiacono L, Tavarini S, Sammicheli C, Laera D, Manetti AGO (2016): Staphylococcus aureus-dependent septic arthritis in murine knee joints: local immune response and beneficial effects of vaccination. Scientific reports 6, 38043

Datta P, Gulati N, Singla N, Vasdeva HR, Bala K, Chander J, Gupta V (2011): Evaluation of various methods for the detection of meticillin-resistant Staphylococcus aureus strains and susceptibility patterns. Journal of Medical Microbiology 60, 1613-1616

Donlan RM, Costerton JW (2002): Biofilms: survival mechanisms of clinically relevant microorganisms. Clinical microbiology reviews 15, 167-193

Dweba CC, Zishiri OT, El Zowalaty ME (2019): Isolation and Molecular Identification of Virulence, Antimicrobial and Heavy Metal Resistance Genes in Livestock-Associated MethicillinResistant Staphylococcus aureus. Pathogens 8, 79

El-Daker M, Meshbah M, El-Naggar MM, Khalil E, El-Kenawy MF (2008): The first two vancomycin resistant Staphylococcus aureus isolates in Mansoura University Hospital; epidemiology and antimicrobial study. Egypt J Med Microbiol 17, 31-43

Espedido BA, Gosbell IB (2012): Chromosomal mutations involved in antibiotic resistance in Staphylococcus aureus. Front Biosci 4, 900-15

Fluit A, Wielders C, Verhoef J, Schmitz F-J (2001): Epidemiology and susceptibility of 3,051 Staphylococcus aureus isolates from 25 university hospitals participating in the European SENTRY study. Journal of clinical microbiology $39,3727-3732$
Gerhardt P, Murray R, Costilow R, Nester EW, Wood WA, Krieg NR, Phillips GB (1981): Manual of methods for general bacteriology.

Gitau W, Masika M, Musyoki M, Museve B, Mutwiri T (2018): Antimicrobial susceptibility pattern of Staphylococcus aureus isolates from clinical specimens at Kenyatta National Hospital. BMC research notes 11, 226

Gould IM, Bal AM (2013): New antibiotic agents in the pipeline and how they can help overcome microbial resistance. Virulence 4, 185-191

Hennekinne J-A, De Buyser M-L, Dragacci S (2012): Staphylococcus aureus and its food poisoning toxins: characterization and outbreak investigation. FEMS microbiology reviews 36, 815-836

Kadry A, Shaker, Ghada, El-Ganiny, Amira, Youssef, Christiana (2016): Phenotypic and Genotypic detection of local MRSA isolates. Zagazig Journal of Pharmaceutical Sciences 25, 39-46

Khattak MS, Bilal M, Rizwan M, Ahmad SAS, Meer A, Ullah I (2015): Staph sensitivty of different phenotypic tests used for detection of staphylococcus aureus in coagulase test. Journal of Medical Sciences 23, 125-129

Kluytmans J, Van Belkum A, Verbrugh H (1997): Nasal carriage of Staphylococcus aureus: epidemiology, underlying mechanisms, and associated risks. Clinical microbiology reviews 10, 505520

Kumari N, Mohapatra T, Singh Y (2008): Prevalence of methicillin-resistant Staphylococcus aureus (MRSA) in a tertiary-care hospital in Eastern Nepal. JNMA J Nepal Med Assoc 47, 53-56

Liang $\mathrm{Y}$, Tu C, Tan C, El-Sayed MAE-G (2019): Antimicrobial resistance, virulence genes profiling and molecular relatedness of methicillin-resistant Staphylococcus aureus strains isolated from hospitalized patients in guangdong Province, china. Infection and Drug Resistance 12, 447 
Lyczak J (2002): Cannon CL, and Pier GB. Lung infections associated with cystic fibrosis. Clin Microbiol Rev 15, 194-222

Manandhar S, Singh A, Varma A, Pandey S, Shrivastava N (2018): Biofilm Producing Clinical Staphylococcus aureus Isolates Augmented Prevalence of Antibiotic Resistant Cases in Tertiary Care Hospitals of Nepal. Frontiers in microbiology 9, 2749

Marais E, Aithma N, Perovic O, Oosthuysen W, Musenge E, Dusé A (2009): Antimicrobial susceptibility of methicillin-resistant Staphylococcus aureus isolates from South Africa. South African medical journal 99

McCann MT, Gilmore BF, Gorman SP (2008): Staphylococcus epidermidis devicerelated infections: pathogenesis and clinical management. Journal of Pharmacy and Pharmacology 60, 15511571

Namvar AE, Asghari B, Ezzatifar F, Azizi G, Lari AR (2013): Detection of the intercellular adhesion gene cluster (ica) in clinical Staphylococcus aureus isolates. GMS hygiene and infection control 8

Pantosti A, Sanchini A, Monaco M (2007): Mechanisms of antibiotic resistance in Staphylococcus aureus.

Projan S (1997): The molecular basis of pathogenicity. The staphylococci in human disease, 55-81

Sanjana R, Shah R, Chaudhary N, Singh Y (2010): Prevalence and antimicrobial susceptibility pattern of methicillinresistant Staphylococcus aureus (MRSA) in CMS-teaching hospital: a preliminary report. Journal of College of Medical Sciences-Nepal 6, 1-6

Stefani S, Chung DR, Lindsay JA, Friedrich AW, Kearns AM, Westh H, MacKenzie FM (2012): Meticillin-resistant Staphylococcus aureus (MRSA): global epidemiology and harmonisation of typing methods. International journal of antimicrobial agents 39, 273-282

Styers D, Sheehan DJ, Hogan P, Sahm DF (2006): Laboratory-based surveillance of current antimicrobial resistance patterns and trends among Staphylococcus aureus: 2005 status in the United States. Annals of clinical microbiology and antimicrobials 5, 2

Tiwari HK, Sapkota D, Sen MR (2008): High prevalence of multidrug-resistant MRSA in a tertiary care hospital of northern India. Infection and drug resistance 1, 57

Verma S, Joshi S, Chitnis V, Hemwani N, Chitnis D (2000): Growing problem of methicillin resistant staphylococci--Indian scenario. Indian journal of medical sciences 54, 535-540

Waters EM, Rowe SE, O'Gara JP, Conlon BP (2016): Convergence of Staphylococcus aureus persister and biofilm research: can biofilms be defined as communities of adherent persister cells? PLoS pathogens 12, e1006012

Weber DJ, Rutala WA (2006): Use of Germicides in the Home and the Healthcare Setting Is There a Relationship Between Germicide Use and Antibiotic Resistance? Infection Control \& Hospital Epidemiology 27, 1107-1119

Winn W, Allen S, Janda W, Koneman E, Procop G, Schreckenberger P, Woods G (2006): Gram-positive cocci part II: streptococci, enterococci, and the "streptococcus-like" bacteria. Koneman's color atlas and textbook of diagnostic microbiology, 6th ed. Lippincott Williams \& Wilkins, Baltimore, MD, 673-764

Wu S, Huang J, Wu Q, Zhang F, Zhang J, Lei T, Chen M, Ding Y, Xue L (2018): Prevalence and characterization of Staphylococcus aureus isolated from retail vegetables in China. Frontiers in microbiology 9,1263 
انتشار واختبار الحساسيه للمضادات الحيويه لعزلات المكورات العنقوديه الذهبيه المفصوله من عينات سريريه

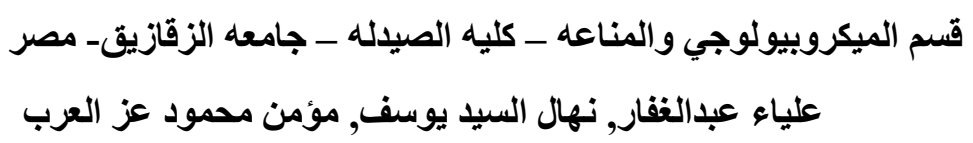

المكورات العنقوديه الذهبيه هي بكتريا موجبه الجرام متعايشه علي الجلد والفم والجهاز التنفسي العلوي مما جعلها

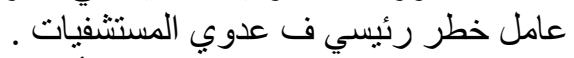

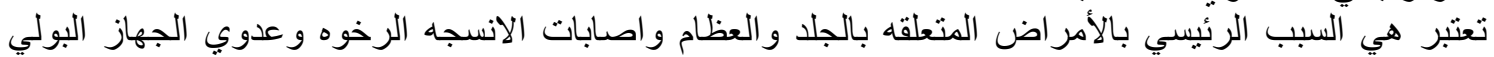

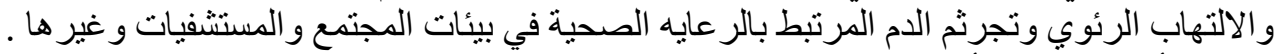

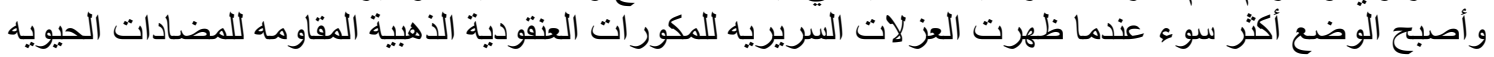

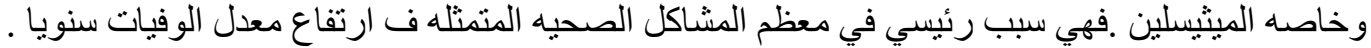

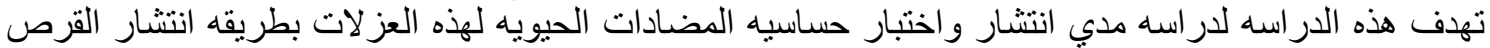

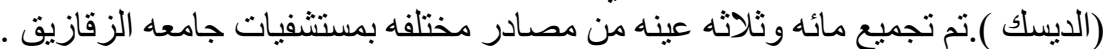

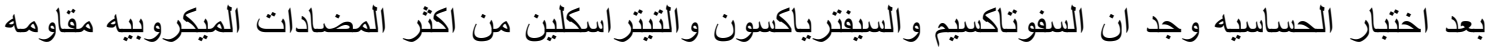

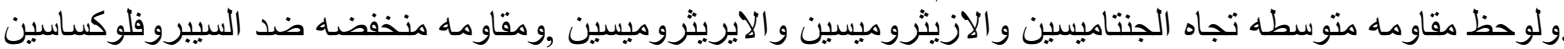

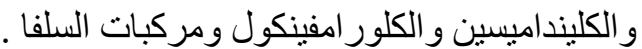
بينما وجد ان الفانكوميسين و اللينزوليد من اكثر المضادات الميكروبيه فعاليه تجاه المكور ات العنقوديه الذهبيه . 